Meta

Journal des traducteurs

Translators' Journal

\title{
Literary Translation and the Problem of Equivalency
}

\section{Karl J. Kuepper}

Volume 22, numéro 4, décembre 1977

URI : https://id.erudit.org/iderudit/003357ar

DOI : https://doi.org/10.7202/003357ar

Aller au sommaire du numéro

Éditeur(s)

Les Presses de l'Université de Montréal

ISSN

0026-0452 (imprimé)

1492-1421 (numérique)

Découvrir la revue

Citer cet article

Kuepper, K. J. (1977). Literary Translation and the Problem of Equivalency.

Meta, 22(4), 243-251. https://doi.org/10.7202/003357ar d'utilisation que vous pouvez consulter en ligne.

https://apropos.erudit.org/fr/usagers/politique-dutilisation/ 


\section{Literary Translation and the Problem of Equivalency}

In a discussion of \& literary translation and the problem of equivalency > two initial terminological ambiguities are encountered. At least on the surface, one of them is fairly easily resolved : in this context « literary translation $>$ refers to the translation of esthetically oriented texts of literary works of art. The other one involves the term \&equivalency 》 which in a discussion of this type cannot be understood in the narrow sense of the Stylistique comparée ${ }^{1}$. It is defined here as the functional equivalency between a text in the source language and its translation in the target language. Equivalency thus appears as the ultimate goal of any translation process. Wolfram Wilss has pointed out that it is symptomatic for the state of the art that we have been unable so far to agree on an unequivocal definition of the term, let alone to describe and classify the conditions under which a translated text can be called equivalent to the original ${ }^{2}$. Even without Harald Weinrich's axiom of the fundamental translatability of any text ${ }^{3}$, however, we are still required to find an objective basis for statements on the quality of a given translation and to define verifiable criteria for that quality, independent of the fact whether we call the translated text an approximate or an equivalent rendering of the original. Consequently, an investigation into the problem of the equivalency or even the quality of a translation of literature should proceed in three steps.

1) The specific features of a literary work of art within a general text theory must be identified and related to an adapted semiotic model.

2) The categories to be applied in the evaluation of a translation must be identified and classified in relationship to actual and potential translation procedures.

3) The categories and criteria thus obtained must be verified by applying them against consistently occurring characteristic features of a specific literary text.

1. To date the series consist of : Jean-Paul Vinay and J. Darbelnet, Stylistique comparée du français et de langlais, Bibliotheque de stylistique comparée, I, new rev. ed. (Paris, Didier, 1967) ; Alfred Malblanc, Stylistique comparée du français et de l'allemand, Bibliothèque de stylistique comparé, II, 4th rev. ed. (Paris, Didier, 1968).

2. Wolfram Wilss, Ubersetzen ", in Handbuch der Linguistik, ed. Harro Stammerjohann (Darmstadt, Wissenschaftliche Buchgesellschaft, 1975), p. 330.

3. Harald Weinrich, Erlernbarkeit, Ubersetzbarkeit, Formalisierbarkeit *, in Theorie und Empirie in der Sprachforschung, ed. H. Pilch and H. Richter (München, Karger, 1970), p. 76-80. 
In the discussion of step 1) reference will be made to the findings of Wolfgang Iser which demonstrate and explain the reasons why a literary text differs substantially from other types of texts ${ }^{4}$. Intuitively this fact has almost invariably been related to the particular problems encountered when trying to translate literature. Unfortunately there have been only few attempts to apply the principles of a textually oriented theory of literature to the problem of the translation of literature.

What makes a literary text different from other types of texts is that it neither directly refers to nor attempts to generate objects in reality. It has been shown that translation procedures can be developed for technical and scientific texts with some degree of success ${ }^{5}$, precisely because they refer to objects in a culture-free reality. Even those texts not referring to objects but specifically designed to generate them, e.g. the platform of a political party or the bylaw of a municipality, offer themselves more readily to cultural and linguistic analyses which, as Yvon Gasse shows, represent a necessary stage in the preparation of the source text for translation ${ }^{8}$. The reason why nonliterary texts open themselves more readily to translation processes becomes apparent in the application of the standard semiotic model to the source text to be translated. Since such texts always have their respective correlative in an objective reality the subject/reader can easily check the information contained in the text against his previous or subsequent experience.

A literary text, on the other hand, does not have a correlative in an objective reality, but rather generates a fictional reality through the reading process. Its meaning cannot be contained in the text but constitutes itself differently each time it is read. The literary text thus offers to the reader concepts and opens up perspectives in which a world known through experiences appears in a different manner. Since there is no direct correspondence between the fictional reality of the text on one hand and the experience of the reader within objective reality on the other hand the reading process will stimulate the reader to reconcile his knowledge of the real world with the fictional reality as it presents itself in the text (Figure D) :

It is the undeterminedness of the literary text with regard to the cultural, social and psychological disposition of the reader as well as to objective reality as he knows it which basically constitutes the essential difference between literary and nonliterary texts. It should be noted that such a definition is not intended to describe exhaustively what represents a literary work of art but it can serve as a working hypothesis for the present discussion.

Turning now to step 2) it becomes plausible that equivalency in the translation of literature is achieved when the text in the target language renders the content with a similar degree of undeterminedness within the relevant categories as the source text. Whether the aim is translation criticism or translating itself, a thorough source text analysis is obviously a precondition if one intends to determine the equi-

4. Wolfgang Iser, Die Appellstruktur der Texte, Unbestimmtheit als Wirkungsbedingung literarischer Prosa (Konstanz, Universitätsverlag, 1971).

5. Rudolph Walter Jumpelt, Die Übersetzüng naturwissenschaftlicher und technischer Literatur, Ma stäbe und Methoden zur Bestimmung ihrer Wesensüge und Probleme (Berlin, Langenscheidt, 1961).

6. Yvon Gasse, * Contextual transposition in translating research instruments *, Meta, 18, 3 (1973), p. 304. 


\section{FIGURE I}

Semiotic Model applied to literary texts

\section{READER}

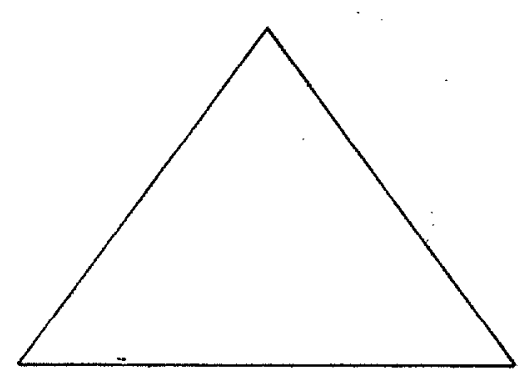

LITERARY TEXT

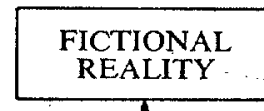

T
Semiotic Model applied to nonliterary texts

SUBJECT /READER

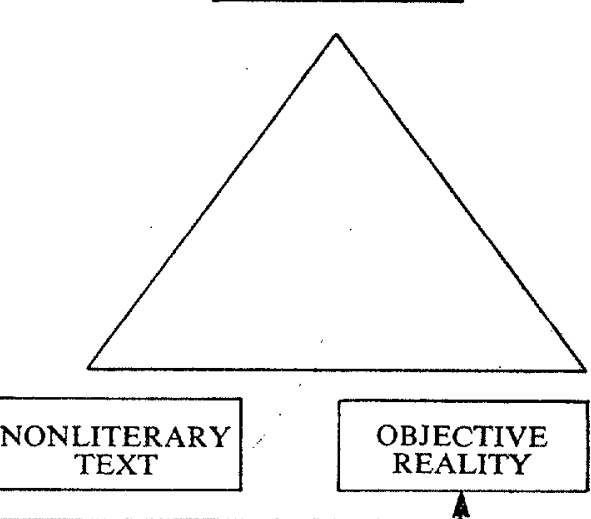

valency of a translation at a later point. For the specific case of a literary text, two analytical phases come into view which in kind and sequence resemble the factors to be considered in an analysis of the intralinguistic reading process, namely the interpretation of the literary features of the text in a first phase and the identification of the cultural, social and psychological conditions which determine the reception of the literary text in a second phase. In a third phase, specific translation procedures are to be considered.

It will be absolutely essential, however; to relate the options and constraints ? of that phase continuously back to the previous phases, and the procedures to be used here will be determined decisively by the literary as well as the cultural, social and psychological properties of the source text (Figure II) :

If the source text were a novel such as J.D. Salinger's The Catcher in the $R y e^{8}$, an example of the literary analysis to be performed in phase one would be to answer a series of questions of the following kind :

What narrative attitude is displayed in the text?

7. The terms * option * and * constraint * correspond to the basic dichotomy * option * vs. * servitude * developed by Vinay and Darbelnet, Stylistique comparée, esp. p. 12 and p. 14 8. Jerome David Salinger, The Catcher in the Rye (Boston, Little, Brown \& Co., 1951). 
FIGURE. II

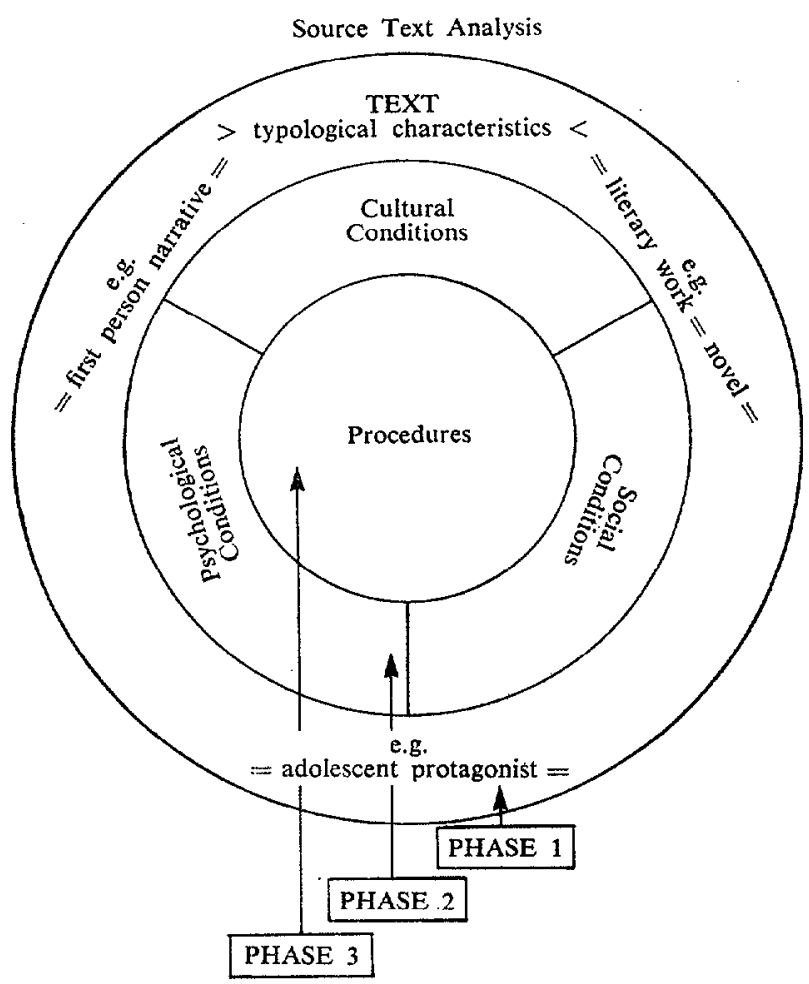

What traits determine the protagonist and the characters who interact with him ?

What meaning is conveyed by the narrative categories of time and space in the text?

Which techniques determine the transitions from one section of the text to the other and how are these sections interrelated?

What levels of speech are to be observed and what function do they fulfill?

What types of metaphorical usage occur and what rôles do they play within the text?

It must be assumed that the selection of such questions and the weight attributed to each of them will depend on the literary text to be examined. A dramatic text, e.g. may well require even greater emphasis on the problem of the interaction of the characters, in the case of a lyric text, on the other hand, one may have to concentrate more on the use of metaphors and imagery.

To stay with the same sample text, phase two would have to investigate the specific cultural, social and psychological conditions which are, on one hand, 
reflected in the text and on the other hand have contributed to the reception of the original then and now. It would, for example, be desirable to inquire into the cultural and social aspects of the educational system, the social and psychological problems of adolescence and childhood and the psychological and cultural phenomena of adaptation to rituals and values, both on the level of the text and on that of its readership. At any rate, the insights gained and the information obtained in phase two will have to be evaluated with regard to their potential representation in the target text and strategies to effect such a transfer will have to be developed.

In phase three the specific translation procedures are to be considered. During the actual translation process such procedures represent a feedback mechanism enabling the translator to examine the adequacy of his translation in terms of the available syntactic and semantic options of the target language. In translation criticism they are determined by comparing sufficiently small segments of the target text with the corresponding segment of the source text. While the general concept of translation procedures as developed by the Stylistique comparée represented an important achievement by making verifiable statements on the nature, and thereby also on the quality, of a translation possible, of the seven specific procedures suggested by Vinay and Darbelnet ${ }^{\circ}$ several are redundant and some even terminologically confusing.

It seems that the following three major categories form an adequate basis to classify translation procedures in a preliminary manner :

\section{Substitution}

The segment in the target language matches the corresponding segment in the source language on the syntactic and the lexical levels. Variations on the morphological level and in word order are acceptable.

\section{Example ${ }^{10}$ :}

SL: English

Franny saw that he was irritated

\section{$S L:$ French}

Un jour nous mourrons, le même jour, le même instant

\section{TL: German}

Franny sah, da $\beta$ er gereizt war

TL : English

One day, we shall die, the same day, the same second

\section{Transposition}

The corresponding segments in the target and source languages differ substantially on the syntactic level, ideally because the syntagm of the source language is either absent or rare in the target language.

9. Stylistique comparée, esp. p. 45-47.

10. The examples were taken from Jerome David Salinger, Franny and Zooey (Boston, Little, Brown \& Co., 1955) ; Jerome David Salinger, Franny and Zooey, trans. Annemarie and Heinrich Böll (Köln, Kiepenheuer \& Witsch, 1963); Samuel Becket, En attendant Godot, quoted by Ekundayo Simpson, a Methodology in translation criticism *, Meta, 20, 4 (1975), p. 260-261. 
Example :

SL: English

He was just standing around smiling and watching

$S L:$ French

Ayant longuement réfléchi
TL : German

Er stand nur da herum, lächelte und sah $\mathrm{zu}$

\section{$T L:$ English}

After prolonged

reflection

\section{Modulation}

The corresponding segments in the target and source languages differ substantially on the lexical level. The agreement of one or more semantic constituents is irrelevant as long as the lexemes will generally not correspond in a different context, e.g. in a dictionary.

\section{Example :}

\section{SL : English}

As though some momentous change of polarity had taken place inside her mind

\section{SL : French}

Lumière aveuglante

\section{TL: German}

Als hätte ein plötzlicher

Spannungswechsel in ihrem

Bewu $\beta$ tsein stattgefunden

\section{$T L:$ English}

Blazing light

Due to the relative length of some segments, e.g. those which have been isolated to identify transpositions, more than one procedure may occur in that segment. If necessary, a more refined system based on the three major categories can be designed by introducing hierarchically arranged subprocedures such as \& amplification », " reduction 》, " concentration », "dilution », " gain » and « loss ». One of the weaknesses of the classifications of the Stylistique comparée is that no hierarchically oriented system is discernible. Since it can safely be assumed that a greater number of substitution procedures are likely only if the source and target languages are closely related, the ratio between the three major categories can serve as a relatively objective measure to describe the degree of similarity between two languages. Structural differences will result in an increase of transpositions, cultural differences in an increase in modulations.

In terms of equivalency the preliminary principle that substitution procedures have priority over transposition procedures and that both have priority over modulation procedures can be established; it would correspond to the old maxim that a translation should be as «literal 》 as possible and as « free 》 as necessary. This principle, which calls for a similarity in form, is however, always superseded by the requirement that any segment of the target text should be similar in function to the corresponding segment of the source text. 
It is now possible to formalize statements on the equivalency of a translation by setting up a matrix adapted to the special situation of the translation of literature ${ }^{11}$.

FIGURE III

Equivalency Matrix

\begin{tabular}{l|l||c|c}
\hline \multicolumn{2}{c}{ Formal Equivalency } & \multicolumn{2}{c}{ Functional Equivalency } \\
\hline $\begin{array}{l}\text { Fictional } \\
\text { Reality } \\
(=<\text { content *) }\end{array}$ & $\begin{array}{l}\text { Transfer of } \\
\text { cultural } \\
\text { social } \\
\text { psychological } \\
\text { data }\end{array}$ & overtranslation & undertranslation \\
\hline $\begin{array}{l}\text { Literary } \\
\text { Text }\end{array}$ & $\begin{array}{l}\text { Substitution } \\
\text { Transposition } \\
\text { Modulation }\end{array}$ & overtranslation & undertranslation \\
\hline
\end{tabular}

In translation criticism the findings can be quantified. If a segment is found to be over- or undertranslated this can be indicated by marking the respective category with a "plus sign; if the translation is found to be adequate the mark will be «zero ». A «zero » in all four categories will signify equivalency.

On level 3 ) the process of verifying the categories and criteria discussed above can by necessity be only of a limited nature. The German translations of some of the fiction of J.D. Salinger shall serve as examples here. When they appeared they almost invariably met with severe criticism ${ }^{12}$, although one of the best contemporary German writers, Heinrich Böll, had a hand in most of them. It is not surprising that very little of such criticism was ever substantiated.

The first example deals with a semantic phenomenon. Holden Caulfield, the protagonist of The Catcher in the Rye, quite frequently ends a thought with the expression "and all », a speech habit of which he is partly aware ${ }^{13}$ and whose importance for the development of the hero and the reception of the novel has been recognized ${ }^{14}$. An analysis of a random sample of 100 occurrences of \& and all $\gg$ in the source text ${ }^{15}$ reveals that in most instances it remained untranslated in the two versions of the target text ${ }^{16}$ :

11. The matrix represents an expanded version of Wolfram Wilss' model in Handbuch der Linguistik, p. 231.

12. E.g. : : Salinger-Mann im Wald s, Der Spiegel, 16, 8 (1962), p. 72-76. Petra Kipphoff, - Die Kunst, einen Autor zu ruinieren », Die Zeit, 22, 8 (1967), p. 25.

13. * Boy ! I said. I also say \& boy * quite a lot. Partly because I have a lousy vocabulary and partly because I act quite young for my age. s The Catcher in the Rye, p. 13.

14. Donald $\mathrm{P}$. Costello, "The language of The Catcher in the Rye \$, American Speech, 34 (1959), p. 172-181.

15. The data were collected by Brigitte Babilon, Vergleichende Untersuchung der ersten deutschen Übersetzung von J.D. Salingers «The Catcher in the Rye » und ihrer Überarbeitung, Thesis P.H. Münster, 1973, p. 117-119.

16. Jerome David Salinger, Der Mann im Roggen, trans. Irene Muehlon (Stuttgart, Diana, $1954)$; J.D. Salinger, Der Fänger im Roggen, revised on the basis of the 1954 translation by Heinrich Böll (Köln, Kiepenheuer \& Witsch, 1962). 
FIGURE IV

Stereotype * and all $\gg$ in J.D. Salinger's The Catcher in the Rye (Sample)

ST : Original (1951)

TT 1 : First German translation Der Mann im Roggen by Irene Muehlon (1954)

TT 2 : Second German translation Der Fänger im Roggen on the basis of TT 1 by Heinrich Böll (1962)

\begin{tabular}{|c|c|c|c|}
\hline ST & TL & TT 1 & $\mathrm{TT} 2$ \\
\hline $\begin{array}{l}\text { and all } \\
(=100)\end{array}$ & $\begin{array}{l}\text { *und so } \\
\text { « und so weiter } \\
\text { * und alles } \\
\text { « und allem } \\
\text { * oder so" } \\
\text { * oder was wei } \beta \text { ich } \\
\text { untranslated = } \varnothing\end{array}$ & $\begin{array}{r}5 \\
14 \\
3 \\
\\
1 \\
1 \\
76\end{array}$ & $\begin{array}{r}25 \\
8 \\
4 \\
1 \\
1 \\
62\end{array}$ \\
\hline & Total : & 100 & 101 \\
\hline
\end{tabular}

In TT 2 an attempt has apparently been made to include some of the previously untranslated occurrences of « und all $\gg$ but the results are rather insignificant. Of the five translations offered « und so » is to be preferred. In view of the great importance of this feature of the protagonist's speech and its cultural, social and psychological implications the principle of equivalency requires that « and all $»$ be consistently translated with « und so $»$.

The second example concerns a morpho-syntactic phenomenon. Both in English and in German reported speech is often marked morphologically, generally by morphemes indicating modality. Although such morphological designations may be considered optional, it is evident that their absence indicates a more immediate relationship between the speaker and the quote and thus throws direct light on his or her attitudes. Since all the major characters in Salinger's story Zooey ${ }^{17}$ are reasonably or well educated their competence to express modality can be assumed. It is suggested here that the striking predominance of unmarked occurrences of reported speech in the story reflects important traits in the main characters. This assumption is supported by the fact that unmarked reported speech occurs significantly more frequently with the more vulnerable characters in the story. The matrix displays both the ratios between marked and unmarked occurrences of reported speech for the major characters as well as their corresponding representations in the German translation ${ }^{18}$ :

17. Franny and Zooey, p. 45-201.

18. Jerome David Salinger, Franny und Zooey, trans. Annemarie \& Heinrich Böll (Köln, Kiepenheuer \& Witsch, 1963), p. 59-242. 
LITERARY TRANSLATION AND THE PROBLEM OF EQUIVALENCY 251

FIGURE V

Reported Speech in J.D. Salinger, Zooey

\begin{tabular}{l|c|c||c|c}
\hline & \multicolumn{2}{c}{ Source Text } & \multicolumn{2}{c}{ Target Text } \\
\hline Character & $\begin{array}{c}\text { Modality } \\
\text { marked }\end{array}$ & $\begin{array}{c}\text { Modality } \\
\text { unmarked }\end{array}$ & $\begin{array}{c}\text { Modality } \\
\text { marked }\end{array}$ & $\begin{array}{c}\text { Modality } \\
\text { unmarked }\end{array}$ \\
\hline $\begin{array}{l}\text { Buddy Glass } \\
\text { (= narrator) }\end{array}$ & 10 & 2 & 12 & $\varnothing$ \\
\hline $\begin{array}{l}\text { Bessi Glass } \\
(=\text { mother) }\end{array}$ & 2 & 7 & 4 & 5 \\
\hline Zooey Glass & 11 & 14 & 20 & 5 \\
\hline Franny Glass & 2 & 20 & 16 & 6 \\
\hline
\end{tabular}

For the characters of Zooey and of Franny the target text distinctly reverses the ratios to be found in the source text. There can be no doubt that modality or its absence is significant for the story. The principle of equivalence therefore requires that instances of reported speech in the source text should appear in the appropriate corresponding marked and unmarked forms. Ultimately such features as stereotype phrases or modality could be shown to contribute substantially to the essential undeterminedness of the literary texts under discussion.

KARL J. KUEPPER 